\title{
Altered pH gradient at the plasma membrane of osteosarcoma cells is a key mechanism of drug resistance
}

\author{
Sofia Avnet ${ }^{1}$, Silvia Lemma ${ }^{1}$, Margherita Cortini ${ }^{1}$, Paola Pellegrini ${ }^{2}$, Francesca \\ Perut $^{1}$, Nicoletta Zini ${ }^{3,4}$, Katsuyuki Kusuzaki ${ }^{5}$, Tokuhiro Chano ${ }^{6}$, Giulia Grisendi ${ }^{7}$, \\ Massimo Dominici7, Angelo De Milito², Nicola Baldini, ${ }^{1,8}$ \\ ${ }^{1}$ Orthopaedic Pathophysiology and Regenerative Medicine Unit, Istituto Ortopedico Rizzoli, Bologna, Italy \\ ${ }^{2}$ Department of Oncology-Pathology, Cancer Center Karolinska, Karolinska Institute, Stockholm, Sweden \\ ${ }^{3}$ CNR - National Research Council of Italy, Institute of Molecular Genetics, Bologna, Italy \\ ${ }^{4}$ Laboratory of Musculoskeletal Cell Biology, Istituto Ortopedico Rizzoli, Bologna, Italy \\ ${ }^{5}$ Musculoskeletal Oncology Unit, Takai Hospital, Nara, Japan \\ ${ }^{6}$ Department of Clinical Laboratory Medicine, Shiga University of Medical Science, Otsu, Shiga, Japan \\ ${ }^{7}$ Department of Medical and Surgical Sciences for Children and Adults, University-hospital of Modena e Reggio Emilia, \\ Modena, Italy \\ ${ }^{8}$ Department of Biomedical and Neuromotor Sciences, University of Bologna, Bologna, Italy
}

Correspondence to: Nicola Baldini, email: nicola.baldini@ior.it

Keywords: osteosarcoma, doxorubicin, drug resistance, plasma membrane pH gradient, tumor microenvironment

Received: April 19, $2016 \quad$ Accepted: August 10, $2016 \quad$ Published: August 22, 2016

\section{ABSTRACT}

Current therapy of osteosarcoma (OS), the most common primary bone malignancy, is based on a combination of surgery and chemotherapy. Multidrug resistance mediated by P-glycoprotein (P-gP) overexpression has been previously associated with treatment failure and progression of OS, although other mechanisms may also play a role. We considered the typical acidic extracellular $\mathrm{pH}(\mathrm{pHe})$ of sarcomas, and found that doxorubicin (DXR) cytotoxicity is reduced in P-gp negative OS cells cultured at pHe 6.5 compared to standard 7.4. Short-time (24-48 hours) exposure to low pHe significantly increased the number and acidity of lysosomes, and the combination of DXR with omeprazole, a proton pump inhibitor targeting lysosomal acidity, significantly enhanced DXR cytotoxicity. In OS xenografts, the combination treatment of DXR and omeprazole significantly reduced tumor volume and body weight loss. The impaired toxicity of DXR at low pHe was not associated with increased autophagy or lysosomal acidification, but rather, as shown by SNARF staining, with a reversal of the $\mathrm{pH}$ gradient at the plasma membrane $\left(\Delta \mathrm{pH}_{\mathrm{cm}}\right)$, eventually leading to a reduced DXR intracellular accumulation. Finally, the reversal of $\Delta \mathrm{pH}_{\mathrm{cm}}$ in OS cells promoted resistance not only to DXR, but also to cisplatin and methotrexate, and, to a lesser extent, to vincristine. Altogether, our findings show that, in OS cells, shortterm acidosis induces resistance to different chemotherapeutic drugs by a reversal of $\Delta \mathrm{pH}_{\mathrm{cm}^{\prime}}$ suggesting that buffer therapies or regimens including proton pump inhibitors in combination to low concentrations of conventional anticancer agents may offer novel solutions to overcome drug resistance.

\section{INTRODUCTION}

Osteosarcoma (OS) is the most common primary malignancy of bone [1]. Since the introduction of multiagent chemotherapy to surgical removal of the primary lesion, the 5-year survival of OS patients has significantly improved, although $30-40 \%$ of localized OS and over $70 \%$ of metastatic OS do not respond to therapy and develop pulmonary metastases [2]. The mechanism of resistance to chemotherapy has been extensively investigated in OS [3-5]. Most studies have focused on pathways modulating cancer cell sensitivity, 
such as the transmembrane ATP-dependent efflux pump P-glycoprotein (P-gp) [3-6], Her-2/ERBB2 [7], the Bcl-2 family proteins [8], and, more recently, miRNAs $[9,10]$. On this respect, however, the role of tumor microenvironment (TME), a key player for tumor cell survival at the primary lesion and the receptive soil for cancer cell seeding at distant sites for the (pre)-metastatic niche [11, 12], has been neglected so far. In many cancers [13-17], including OS [18, 19], a number of TMEdependent factors may play a key role in chemoresistance, including the modification of the extracellular matrix, the recruitment of stromal cells, and hypoxia. The hypoxic TME of OS, an osteogenic malignancy usually arising in bone, may be particularly relevant for tumor behavior. In fact, bone is per se a hypoxic tissue with an oxygen tension between $<1 \%$ in hypoxic region and $<6 \%$ in proximity of sinusoidal cavities [20], and it is well known that hypoxia controls a number of relevant bone tissuespecific activities, including angiogenesis, recruitment of stem precursors, proliferation, and differentiation of committed osteogenic elements [21]. Tumor cells cope with hypoxia by switching from aerobic respiration to glycolysis, in turn producing lactic acid and causing extracellular acidosis [22]. In several malignancies, the increased reliance on glycolysis to produce energy occurs even in the presence of sufficient oxygen supply [23, 24]. Indeed, the extracellular $\mathrm{pH}(\mathrm{pHe})$ of different tumor types, including sarcomas, ranges from 6.4 to 7.3 , whereas the $\mathrm{pHe}$ of normal tissues is in the range of 7.2-7.5 [25]. Locally and acutely, intratumoral $\mathrm{pH}$ varies from one area to another, showing a trend of decrease that in the long term (chronically) results into an average persistent intratumoral acidosis. Indeed, $\mathrm{pH}$ can locally and rapidly change due to a short-lived phenomenon, like to apoptosis of a small group of cells, to temporary hypoxia due to the disruption of small vessels, or to temporary high glycolytic activity $[26,27]$. As a result, in the tumor TME, acidosis is both chronic and acute, with different grading. We have recently demonstrated in sarcomas that a low pHe is linked to malignant behavior [28, 29]. In other cancers, acidity has also been associated with drug resistance [30-32].

In this study, we studied the role of $\mathrm{pH}$ regulation on drug resistance of OS. For this purpose, in wild type OS cells we investigated doxorubicin (DXR) cytotoxicity and intracellular accumulation under acidic conditions, the role of lysosomal acidification and autophagy on drug resistance, and the effects of lysosomal $\mathrm{pH}$ modification both in vitro and in vivo. We investigated on the effect of rapid changes in $\mathrm{pH}$ on drug effectiveness. Our results show that, besides P-gp overexpression, extracellular acidity is another major player of resistance to DXR, suggesting the use of $\mathrm{pH}$ modifiers as novel therapeutic tools to increase the efficacy and reduce toxicity of conventional anticancer agents.

\section{RESULTS}

\section{The acidic TME of OS is associated with resistance to DXR}

As proof-of-principle that our in vitro models were representative of the acidic TME of OS, we verified if the preselected $\mathrm{pHe}$ (culture medium at $\mathrm{pH}$ 6.5-7.4-8.0) at the beginning of the culture, with or w/o DXR, was maintained over the incubation period. We checked the $\mathrm{pH}$ of medium at different time points for all the OS cell lines included in this study and it was very similar between the different cell lines. After $72 \mathrm{~h}$, the pHe was slightly decreased, possibly due to the high number of subconfluent cells. However, the specific pHe values were stable over the culture period (Figure 1A, representative values only for HOS cells). As expected, due to its cationic nature, DXR induced a trend of a slight increase in $\mathrm{pHe}$ at all conditions. In unbuffered medium, HOS cells secreted an amount of protons that, combined with the $5 \%$ of atmosphere $\mathrm{CO}_{2}$, induced a pHe of around 6.8 (at $48 \mathrm{~h}$ : $6.76 \pm 0.09, n=6$, Figure 1A).

We then sought to investigate whether the reduced cytotoxicity of DXR under an acidic TME was present in OS cells, even if they do not express P-gp, as previously observed in other cancers [31-33]. Indeed, following DXR exposure, the percentage of growth inhibition of OS P-gp negative cells calculated by direct cell counting significantly correlated with the $\mathrm{pH}$ values (Figure 1B). By indirect viability test, we also found that, at $\mathrm{pHe} 6.5$, the concentration of DXR needed to obtain $60 \%$ of growth inhibition in the same cells was 10-fold higher than at pHe 7.4 (Figure 1C). The same type of indirect test was also used to calculate EC50 of DXR at different pH. EC50 at $\mathrm{pH} 6.5$ was around 2,000-fold higher with respect to pH 7.4 in P-gp negative cells, whereas the expression of P-gp in HOS 100-DXR cells that we used as positive control for chemoresistance (P-gp positive cells) induced an increase of the EC50 value of only 500-fold in respect to sensitive (P-gp negative) cells (Table 1). To exclude the possibility that the reduced DXR cytotoxicity of OS cells cultured at low pHe was due to cell death promoted by acidity, we used Annexin- $\mathrm{V}$ test. We found no difference in apoptosis in untreated HOS P-gp negative cells cultured at acidic $\mathrm{pH}$ in respect to neutral $\mathrm{pH}$ (Supplementary Figure S1, CTR), whereas DXR-treated P-gp negative cells showed a significantly higher induction of apoptosis under neutral $\mathrm{pH}$ in respect to cells cultured at $\mathrm{pH} 6.5$ (Supplementary Figure S1, DXR $50 \mathrm{ng} / \mathrm{mL}$ ). Interestingly, culturing sensitive cells (P-gp negative cells) at acidic $\mathrm{pHe}$ for $48 \mathrm{~h}$ was sufficient to completely impair DXR nuclear accumulation (Figure 1D and 1E). Resistance to DXR mediated by acidic pHe in sensitive cells was not associated with the induction of P-gp expression by acidosis since HOS P-gp negative cells were still negative 


\begin{tabular}{lcc}
\hline & DXR [ng/mL] & $\boldsymbol{R}^{2}$ \\
\hline pHe 6.5 & 2303.40 & 0.9952 \\
pHe 7.4 & 1.37 & 0.9978 \\
HOS 100-DXR & 505.49 & 0.9599 \\
\hline
\end{tabular}

for the expression of P-gp protein also when cultured at pH 6.5 for 1 month (Figure 1F, HOS 100-DXR P-gp positive cells are the positive control).

\section{Low pHe enhances lysosomal activity but not the autophagic flux}

The doubling rate of OS sensitive (P-gp negative) cells cultured under acidity was 1.5-2.6 times slower than under standard conditions (Table 2), and this reduced doubling rate is possibly partially causing the impaired cytotoxicity of DXR.

We next reasoned to assess the role of lysosomal acidification on the acid-induced chemoresistance. The number of lysosomes of HOS cells was increased and lysosomes appeared also more activated when cultured in acidic medium, as shown by the presence of a higher number of residual bodies detected by electron
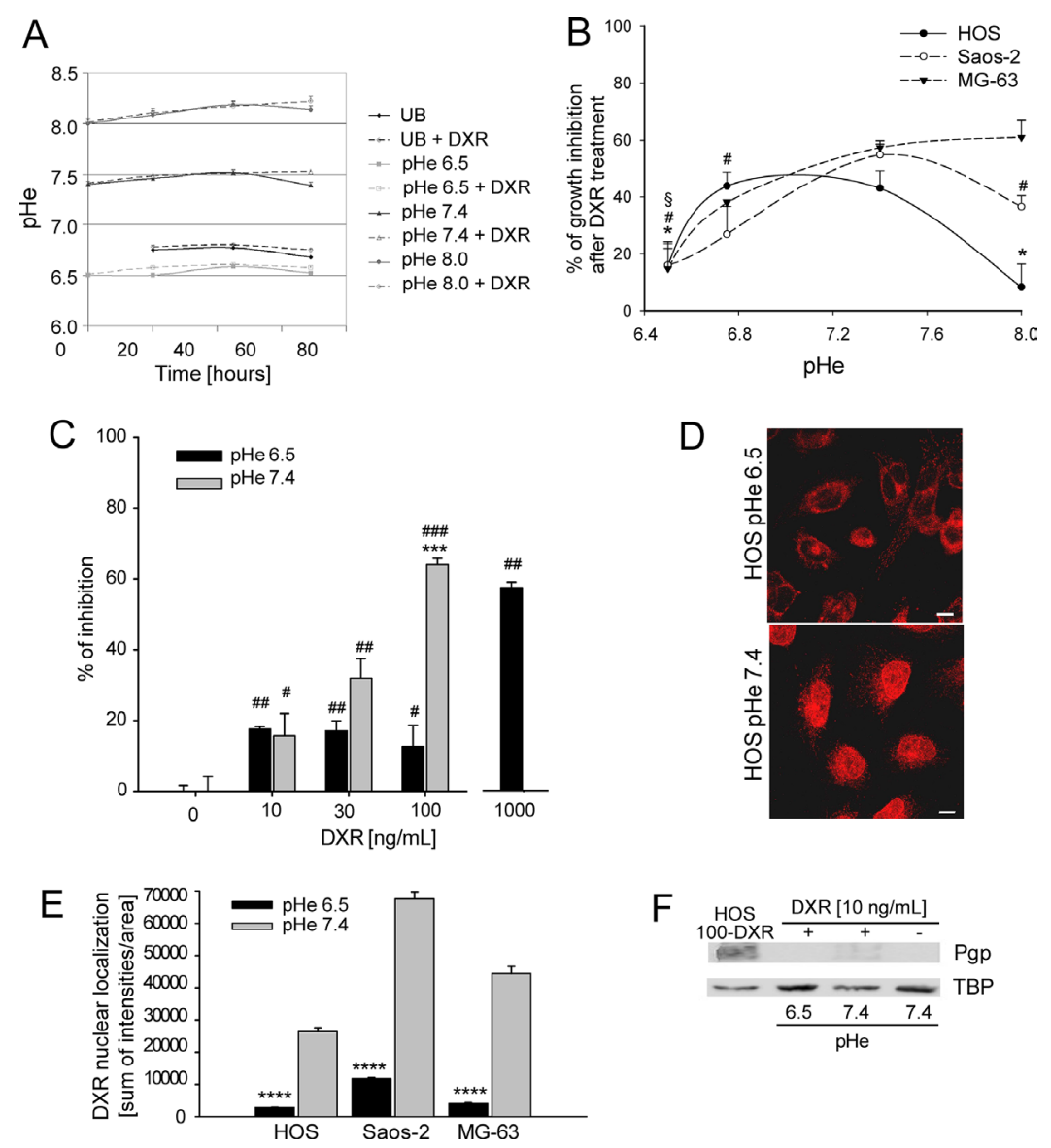

Figure 1: Chemoresistance induced by low pHe. (A) Measurement of $\mathrm{pH}$ of medium buffered at different $\mathrm{pH}$ and unbuffered (UB), over the culture period; (B) percentage of growth inhibition of osteosarcoma (OS) P-glycoprotein (P-gp) negative cells cultured at different $\mathrm{pH}$ and treated with Doxorubicin (DXR) $(15 \mathrm{ng} / \mathrm{mL})$ by direct cell counting. Growth inhibition was obtained in respect to the untreated condition at the respective $\mathrm{pH}\left({ }^{*} p<0.05 \mathrm{vs} \mathrm{pH} 7.4\right.$ for HOS; ${ }^{*} p<0.05 \mathrm{vs} \mathrm{pH} 7.4$ for Saos-2; ${ }^{\S} p<0.05 \mathrm{vs} \mathrm{pH} 7.4$ for MG-63); (C) Percentage of growth inhibition of HOS P-gp negative cells at different concentrations of DXR under acidic conditions by viability

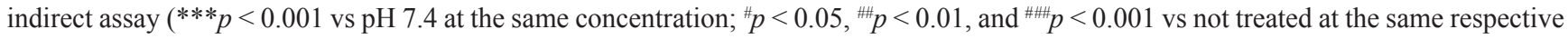
$\mathrm{pH}$ ); (D) DXR nuclear compartmentalization in HOS P-gp negative cells maintained at different $\mathrm{pH}$ for $48 \mathrm{~h}$, observation at the confocal microscope (Scale bars $=5 \mu \mathrm{m}$ ). (E) Fluorescence intensity of DXR in the nuclei of OS P-gp negative cells treated with $10 \mathrm{mg} / \mathrm{mL}$ DXR $(* * * * p<0.0001)$; (F) western blotting analysis of Pgp expression in HOS P-gp negative cells at different $\mathrm{pHe}$ and treated or not treated with DXR for 30 days. HOS 100-DXR P-gp positive cells were used as positive control. HOS 100-DXR cells were obtained after continuous exposure to DXR for several months at $\mathrm{pHe} 7.4$. 
Table 2 : Doubling time of OS cell lines at different $\mathrm{pHe}$

\begin{tabular}{lccc}
\hline & pHe 6.5 & pHi 7.4 & p \\
\hline HOS & $33.0 \pm 0.6(n=4)$ & $14.3 \pm 0.7(n=4)$ & 0.0209 \\
MG-63 & $72.3 \pm 13.8(n=5)$ & $28.2 \pm 2.7(n=4)$ & 0.0143 \\
Saos-2 & $38.3 \pm 2.0(n=5)$ & $25.1 \pm 4.4(n=4)$ & 0.0275 \\
\hline
\end{tabular}

microscopy, with respect to the neutral condition (Figure 2A). To determine lysosomal pH, cells were costained with Lysotracker and Lysosensor fluorescent dyes that showed selective accumulation in the lysosomal compartment. Cells cultured under acidic conditions had a striking increase in the number of acidic vesicles and thus a lower vesicular $\mathrm{pH}$ (Figure 2B). To further extend these findings, we performed quantitative measurement of the intensity of the fluorescence emission spectra of Acridine Orange (AO) uptaken by single cells at different wavelengths. $\mathrm{AO}$ is a probe for measuring $\mathrm{pH}$ gradients across membranes with particular specification to intravesicular acidification. Indeed, MG-63 cells cultured in acidic medium showed a shift from the green (alkaline) to the red (acidic) emission wavelength, indicating acidification of lysosomes (Figure 2C). Furthermore, the number of lysosomes per single cell was significantly increased (Figure 2C). Lysosomal activity is strongly associated with mTOR activity, and the recovery of the autophagic flux is associated with the early inhibition of mTOR phosphorylation, previously reported to occur during acidic stress $[34,35]$. Therefore, we investigated whether OS sensitive cells under acidic conditions showed an altered transcriptome related to the mTOR. This, however, was not the case: in fact, after $24 \mathrm{~h}$ we did not observe any significant variation of the transcripts related to the mTOR pathway (Supplementary Figure S2).

Staining for the autophagic markers LC3 (green) and lysotracker (red) showed the presence of LC3-positive lysosomes (Figure $3 \mathrm{~A}$ ). In order to understand how low $\mathrm{pH}$ modulates autophagy in OS cells, we performed kinetics analysis of the autophagic flux in HOS cells after $48 \mathrm{~h}$. During autophagy, the cytosolic form of LC3 (LC3-I) is lipidated to the autophagosome-associated form (LC3II) which is then degraded after fusion with lysosomes. Measurement of the autophagic flux is determined by the accumulation of LC3-II protein in the presence of the lysosomal inhibitor bafilomycin A1 (BafA1) and expressed as the ratio of LC3-II signal intensity in cells with and without BafA1 and normalized for the actin signal [36]. Despite a temporary but minor downregulation of the autophagic flux at 4-8 h, cells were fully competent for autophagy at 24 and $48 \mathrm{~h}$, as indicated by the similar accumulation of LC3-II in the presence of BafA1 in the two $\mathrm{pH}$ conditions (Figure 3B and Supplementary Figure S3). The ability of HOS cells to maintain a high self-degradative process after exposure for $24 \mathrm{~h}$ at $\mathrm{pH} 6.5$ was also confirmed by using other lysosomal inhibitors
(Figure 3C). Since upregulation of the autophagy modulator HMGB1 was reported to mediate DXR resistance in OS [37], we evaluated the effects of acidosis on intracellular HMGB1 levels in HOS cells. Both DXR and acidity per se induced the expression of HMGB1 in HOS cells (Figure 3C and 3D and Supplementary Figure S4). Despite this, treatment with DXR did not affect the autophagic flux in HOS cells in neither of the $\mathrm{pH}$ considered (Figure 3D and Supplementary Figure S5). In order to study whether the maintenance of autophagy in acidic conditions was associated with sensitivity to DXR in HOS cells, we performed transient siRNAmediated knock-down of Atg5, a gene involved in autophagosome maturation. After efficient knockdown of Atg5 (Supplementary Figure S6), cells were exposed to medium at $\mathrm{pH} 7.4$ or $\mathrm{pH} 6.5$ and treated or not treated with DXR. Analysis of cell death showed that inhibition of autophagy does not affect the sensitivity to DXR under either pHe (Figure 3E). In addition, cells cultured at acidic $\mathrm{pH}$ maintained DXR resistance independently of autophagy. In conclusion, these findings show that modulation of autophagy during acidity is not involved in DXR resistance of OS cells.

\section{Targeting lysosomal activity enhances the DXR effectiveness}

To confirm that the autophagy-independent lysosomal activity is involved in DXR response after shortterm acidosis, we used omperazole (OME), a proton pump inhibitor that targets lysosomal acidification by blocking vacuolar-ATPase (V-ATPase) activity in sarcoma cells $[29,38]$. Treatment with OME enhanced growth inhibition promoted by DXR under acidity. Especially in HOS and MG-63 sensitive cells, DXR treatment showed a significant effect at lower doses, when used in combination with OME, with respect to the single treatment (Figure 4A).

Similar results were obtained in vivo in a xenograft model of OS. When both intraperitoneally administered, combined treatment with OME $(10 \mathrm{mg} / \mathrm{kg})$ enhanced the cytotoxic effect of DXR $(1.5 \mathrm{mg} / \mathrm{kg})$, resulting in a significantly lower tumor volume and a higher necrotic index (Figure 4B-4D). Interestingly, mice treated with the combination of OME and DXR showed a statistically significant reduced loss of body weight compared to mice treated with DXR alone (DXR treated group: $20.1 \pm 0.6 \mathrm{gr}$; OME + DXR treated group: $22.3 \pm 0.6 \mathrm{gr} ;{ }^{*} p<0.05$ ), possibly suggesting that OME reduced DXR toxicity. 


\section{Altering the $\mathbf{p H}$ gradient at the plasma membrane is a key mechanism of drug resistance}

We then sought to investigate the total amount of DXR that effectively enters into the OS sensitive (P-gp negative) cells cultured under acidic conditions through image analysis (Figure 5A) and flow cytometry (Figure 5B). A low fluorescent signal of the drug was detected within the cells at acidic $\mathrm{pH}$ in respect to neutral conditions both at 24 and $48 \mathrm{~h}$ (Figure 5B). This finding suggests that the major obstacle for DXR effectiveness under short-term acidosis is its entrance into the cell through the plasma membrane. This is possibly due either to a phenomenon known as the partition theory, or through a change of membrane stiffness, both related to a reversal of the $\Delta \mathrm{pH}_{\mathrm{cm}}$ [33]. To extend this observation, we used SNARF staining in living cells and observed a significant alteration of $\Delta \mathrm{pH}_{\mathrm{cm}}$ that would result in an enhancement of intracellular positive charge with respect to the extracellular space (Figure 5C). The alteration of $\Delta \mathrm{pH}_{\mathrm{cm}}$ showed a trend of reduction in MG-63 cells and a significant reduction in Saos-2 sensitive (P-gp negative) cells when cells were treated with OME (Figure 5C). Interestingly, we found that the same pattern of an altered $\Delta \mathrm{pH}_{\mathrm{cm}}$ was also present in P-gp expressing resistant OS cells cultured in a standard medium at $\mathrm{pH} 7.4$, with respect to the sensitive P-gp negative parental cells also cultured in standard medium at $\mathrm{pH} 7.4$ (Figure 5D). The use of the MDR modifier verapamil produced a decrease of this effect, whereas the incubation with a MDR-1 neutralizing
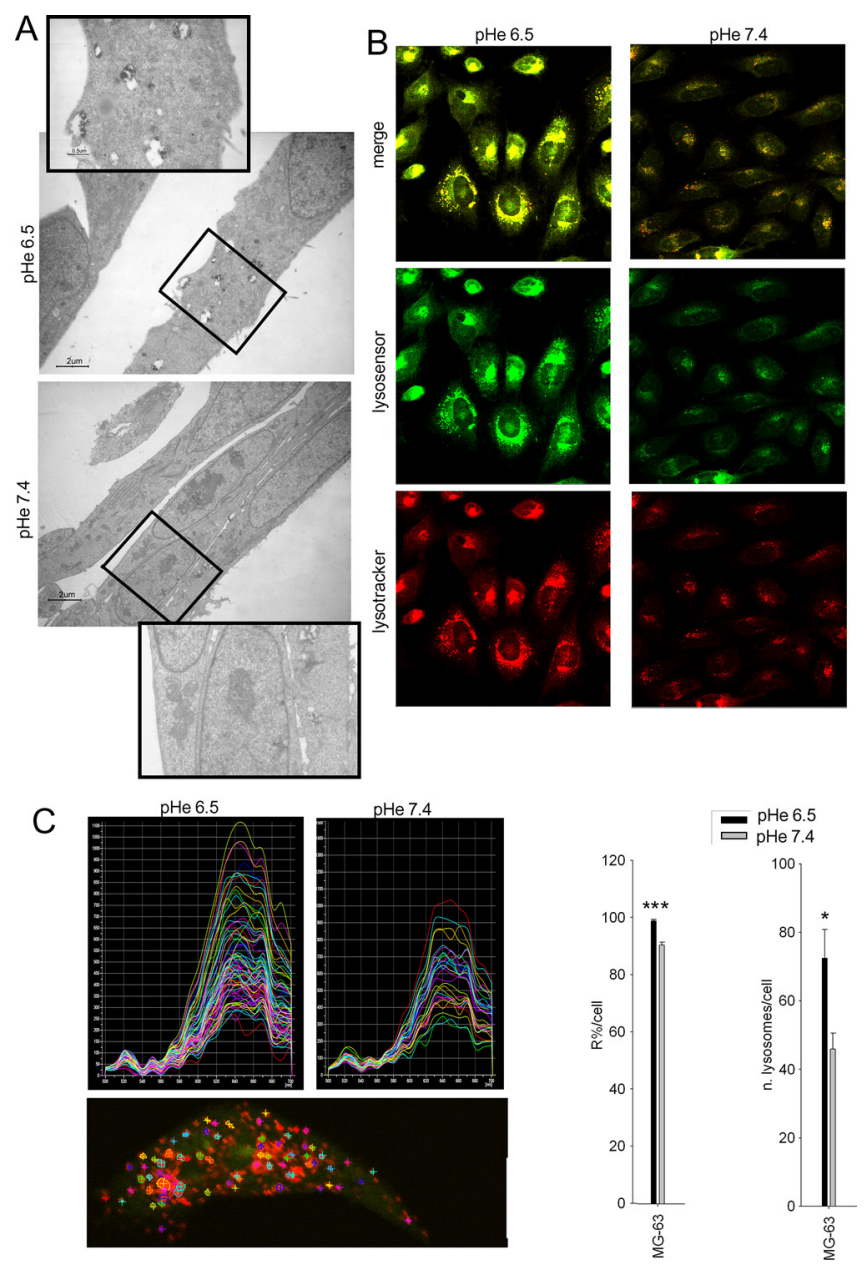

Figure 2: Lysosomes in cells under acidic conditions are more acidic and increased in number. OS cells were maintained for $48 \mathrm{~h}$ at different $\mathrm{pHe}$ before analyses. (A) trasmission electron microscopy of HOS cells (in the rectangles, a detail of the original image is enlarged); (B) lysosensor (green) and lysotracker (red) staining of HOS cells; (C) spectrum analysis of Acridine Orange (AO) emission in vesicle-like structure in HOS cells. AO is a probe for measuring $\mathrm{pH}$ gradients across membranes with particular specification to intravesicular acidification, with a trend of localization and subsequent accumulation and polymer formation (emission at $655 \mathrm{~nm}$ ) in acidic compartment, and of monomer localization at higher $\mathrm{pH}$ (emission at $530 \mathrm{~nm}$ ). Upper panels: representative graphs of the intensity of spectra of all the lysosomes within a cell at the two different pHe; lower panel: representative image of intracytoplasmic area examined; right panel: quantification of the lysosomal acidity by spectra analysis $\left[\mathrm{R} \%=100 * \mathrm{I}_{655} /\left(\mathrm{I}_{655}+\mathrm{I}_{530}\right)\right.$ where $\mathrm{I}_{655}$ and $\mathrm{I}_{530}$ are the green $(520-540 \mathrm{~nm})$ and the red $(645-665 \mathrm{~nm})$ integrated emission intensities, $* * * p<0.0001 \mathrm{vs} \mathrm{pHe} 7.4)]$, and number of acidic vesicles within a cell $(* p<0.05$ vs $\mathrm{pHe} 7.4)$. 
antibody significantly impaired this effect, completely restoring the original phenotype (Figure 5E). These results suggest that chemoresistance mediated also by $\mathrm{P}$-gp activity is partially due to $\mathrm{pHi}$ regulation. Finally, we found that drug resistance promoted by short-term acidosis is not specific only to DXR, since the treatment with methotrexate, vincristine, and at a lower extent with cisplatin was significantly impaired by low pH (Figure 6). As a control we used P-gp expressing cells in which a very high resistance to DXR and vincristine, and only a low resistance to cisplatin and methotrexate were present. Notably, drug resistance conferred by short-term acidosis was dramatically higher for methotrexate, and less evident with vincristine. In the first case, it is likely that BCRP cancer resistance proteins that efflux methotrexate out of the cells and that are expressed by OS cells [39], transport more efficiently the drug at low $\mathrm{pH}$ [40]. Regarding vincristine, the mild effect of $\mathrm{pH} 6.5$ on resistance is
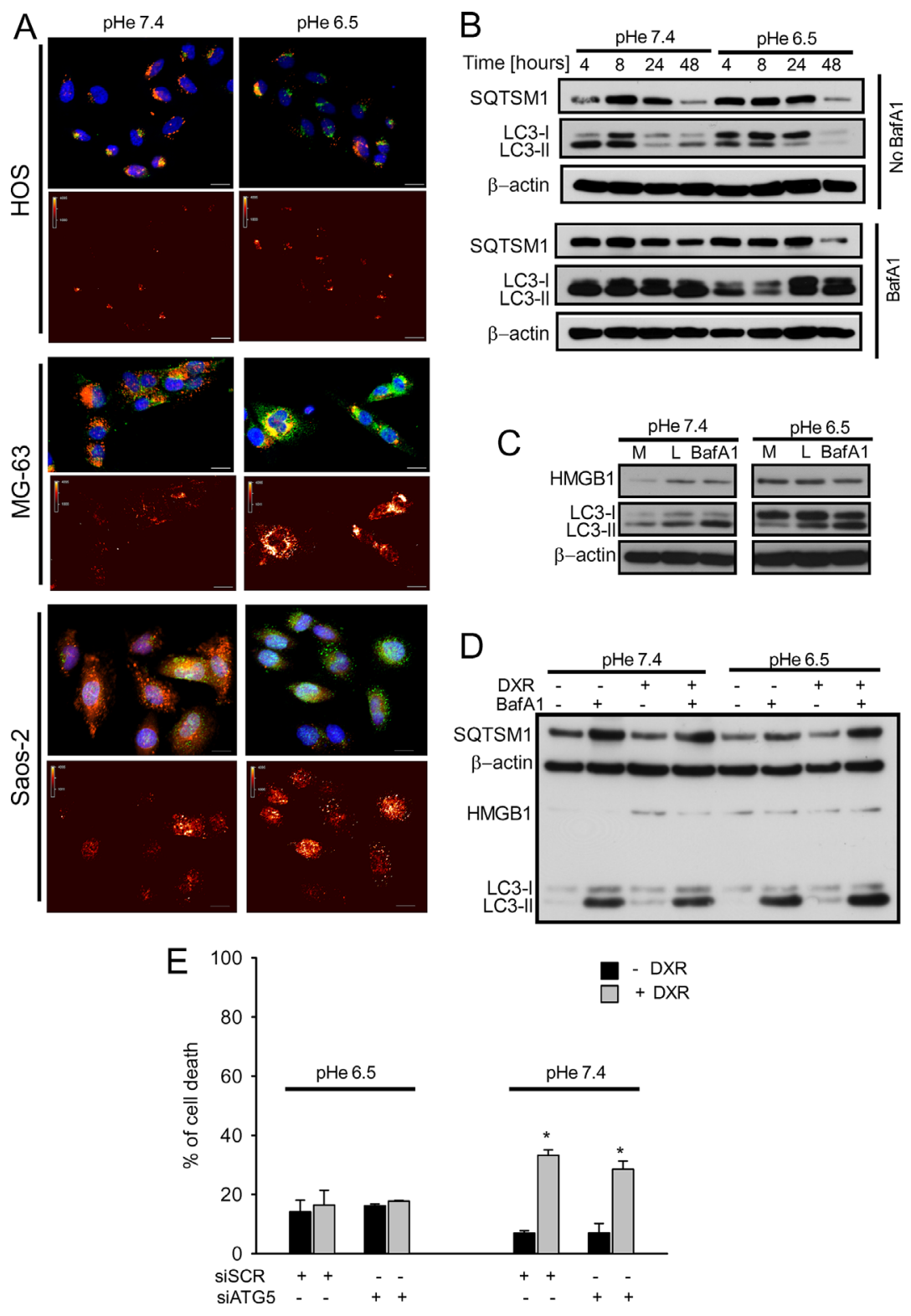

Figure 3: Autophagic flux was unaffected in OS cells cultured under acidic conditions. (A) Upper panel: LC3-B immunostaining (green), with LysoTracker staining (red), and nuclei staining (blue) under different pH (scale bar $10 \mu \mathrm{m}$ ). Lower panel: false color for LC3-B staining showed in the upper panel; (B) analysis of autophagic flux by western blotting of LC3B and SQTSM1 expression of HOS cells cultured at pH 7.4 and 6.5 at different $\mathrm{pH}$ and at different time-points (4-8-24-48- hrs) in presence of absence of BafA1treatment $(50 \mathrm{nM})$ for $2 \mathrm{~h}$ before collection; (C) western blot analysis of proteins related to the autophagic flux HMGB1 and LC3-II in HOS cells cultured at $\mathrm{pH} 7.4$ and 6.5, in presence of BafA1 $(50 \mathrm{nM})$ for $2 \mathrm{hrs}$ before collection, or of the lysosomal inhibitors (L, Pepstain A/E64d) treatments at $10 \mu \mathrm{g} / \mathrm{mL}$, or with complete medium (M); (D) western blot analysis HMGB1, LC3-II, and SQTSM1 in HOS cells treated for $24 \mathrm{~h}$ with DXR, in presence or absence of BafA1 at different $\mathrm{pH}$ (7.4 and 6.5); (E) evaluation of the effect of the silencing of autophagic protein ATG5 on HOS cell death, under acidic conditions in HOS cells $(* p<0.05$ vs not treated cells at the respective $\mathrm{pH})$. 
possibly due to the very acidic pKa of the drug (between 3.5 and 4.5) that is thus less subject to the reversal of $\Delta \mathrm{pH}_{\mathrm{cm}}$.

\section{DISCUSSION}

Since the time of discovery of MDR mediated by P-gp expression [41], the concept of chemoresistance has been extensively revised and expanded into two major types. Biochemical resistance is mediated by the upregulation of drug efflux or metabolic pathways, such as MDR-1 or BCRP. Moreover, physiological resistance may also occur as a consequence of poor perfusion, hypoxia, and/or acidity [42].

In this study, we mimicked the acidic conditions of extracellular space that are commonly detected in OS as a result of the significant anomalies in energy metabolism by using in vitro cell culture medium buffered at $\mathrm{pH} 6.5$. Under these conditions, we observed that the growth inhibition of OS sensitive (P-gp negative) cells induced by DXR was significantly impaired. In fact, at $\mathrm{pH} 6.5$, a 10 -fold increase of DXR concentration was necessary to achieve the same level of growth inhibition detected

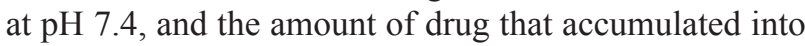
the nucleus, the main target site of DXR activity, was significantly reduced.

Therefore, the effect of $\mathrm{pH}$ on DXR resistance did not rely on P-gp expression, and might be attributed to different mechanisms. We observed a reduced replication rate at $\mathrm{pHe} 6.5$, possibly due to a block in cell cycle [43], and this might interfere with the effectiveness of an antiproliferative agent, like DXR, blocking type II topoisomerase activity [44]. Another possible explanation concerns lysosomal acidification. Acidic lysosomes can sequester weakly basic molecules, like DXR, to an extent that is directly related to the level of acidity $[45,46]$. The compartmentalization into the lysosomes might derive from the transfer of DXR from the cytosol, or from a
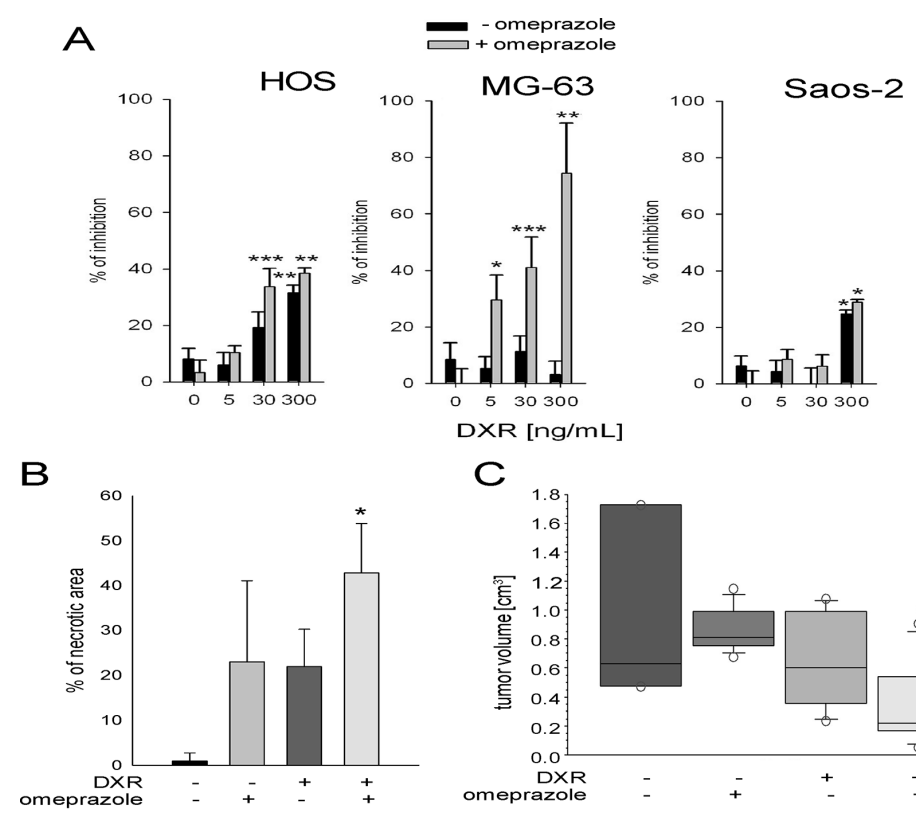

C
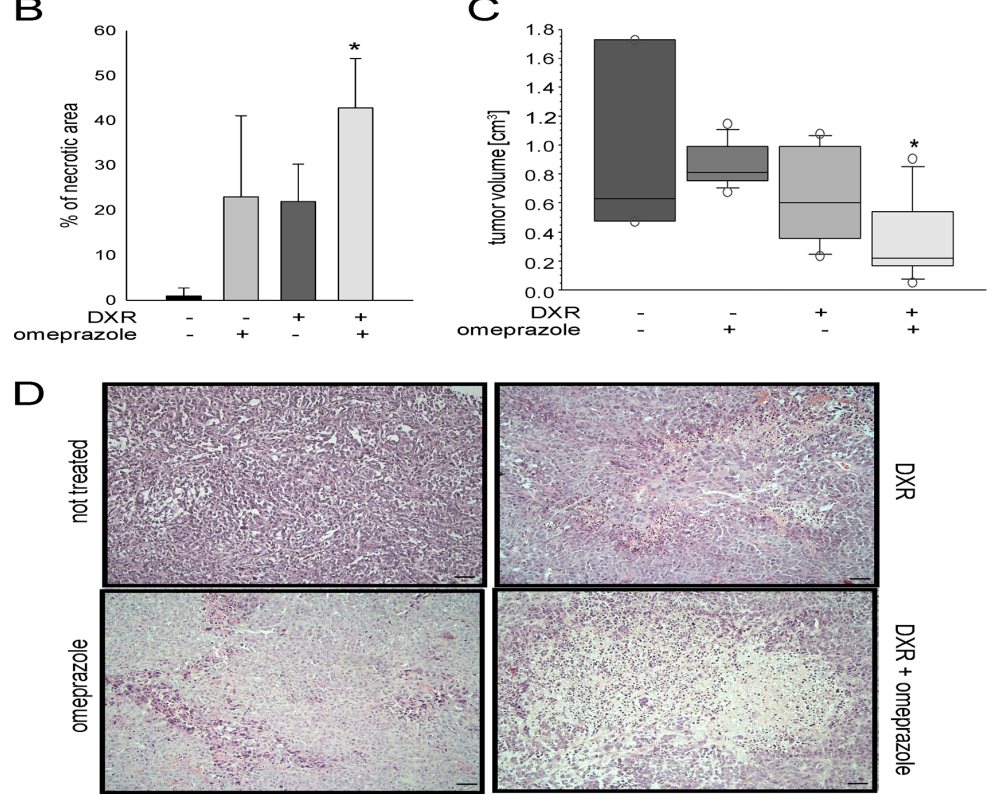

Figure 4: Lysosomal targeting enhanced DXR cytotoxicity. (A) Cells were treated with DXR for 48 h under acidity following pretreatment of $2 \mathrm{~h}$ with (+ OME) or without (- OME). The percentage of inhibition was obtained by an indirect viability assay $(* p<0.05$, ${ }^{* *} p<0.01$, and ${ }^{* * *} p<0.001$ vs not DXR treated cells, at the respective +OME or - OME condition); (B) percentage of necrotic area in a mouse model of OS treated with DXR in combination or not with OME ( ${ }^{*} p<0.05$ vs non treated group); (C) Tumor volume in the same xenografts ( ${ }^{*} p<0.05$ vs non treated group); (D) ematoxylin \& eosin staining of xenograft sections, representative images (scale bar $=100$ micrometers). 
direct endocytotic process [47]. Compared to standard conditions, in OS cells cultured for a few hours in acidic medium, we found a higher number of larger lysosomes and, as already demonstrated for breast cancer cells [46], the lysosomal compartment was also more acidic.

Closely associated to lysosomal acidification, autophagy is an adaptation mechanism that cancer cells adopt when exposed to an adverse microenvironmental conditions, such as acidity $[35,48]$ and anticancer agents, including DXR [37]. After $24 \mathrm{~h}$ exposure to acidity, however, we did not observe changes in the expression of autophagy-related genes. Such a short endpoint was selected to parallel the rapid nuclear uptake of DXR.
Although treatment with DXR or with acidic pHe increased HMGB1 expression, the inhibition of autophagy via knock-down of Atg5 did not alter the sensitivity of OS cells to DXR at any pHe condition, further suggesting that autophagy-mediated DXR resistance is not a general phenomenon in OS cells.

We further investigated the role of lysosomes in OS chemoresistance under short-term acidic conditions, and independently of autophagy. We have previously shown that treatment with OME, a gastric $\mathrm{H}+/ \mathrm{K}+$-ATPase inhibitor that targets also the lysosomal proton pump V-ATPase [49], alkalinizes lysosomal $\mathrm{pH}$ in sarcoma cells $[29,38]$. Here, we reasoned to test the effects of
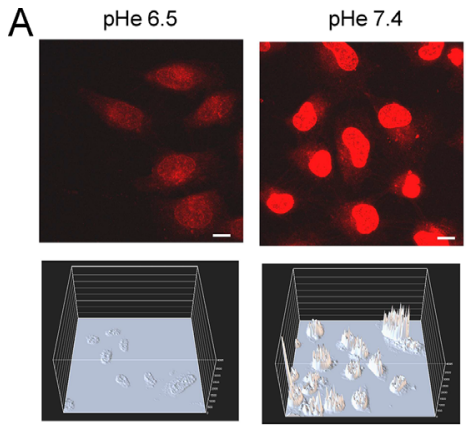
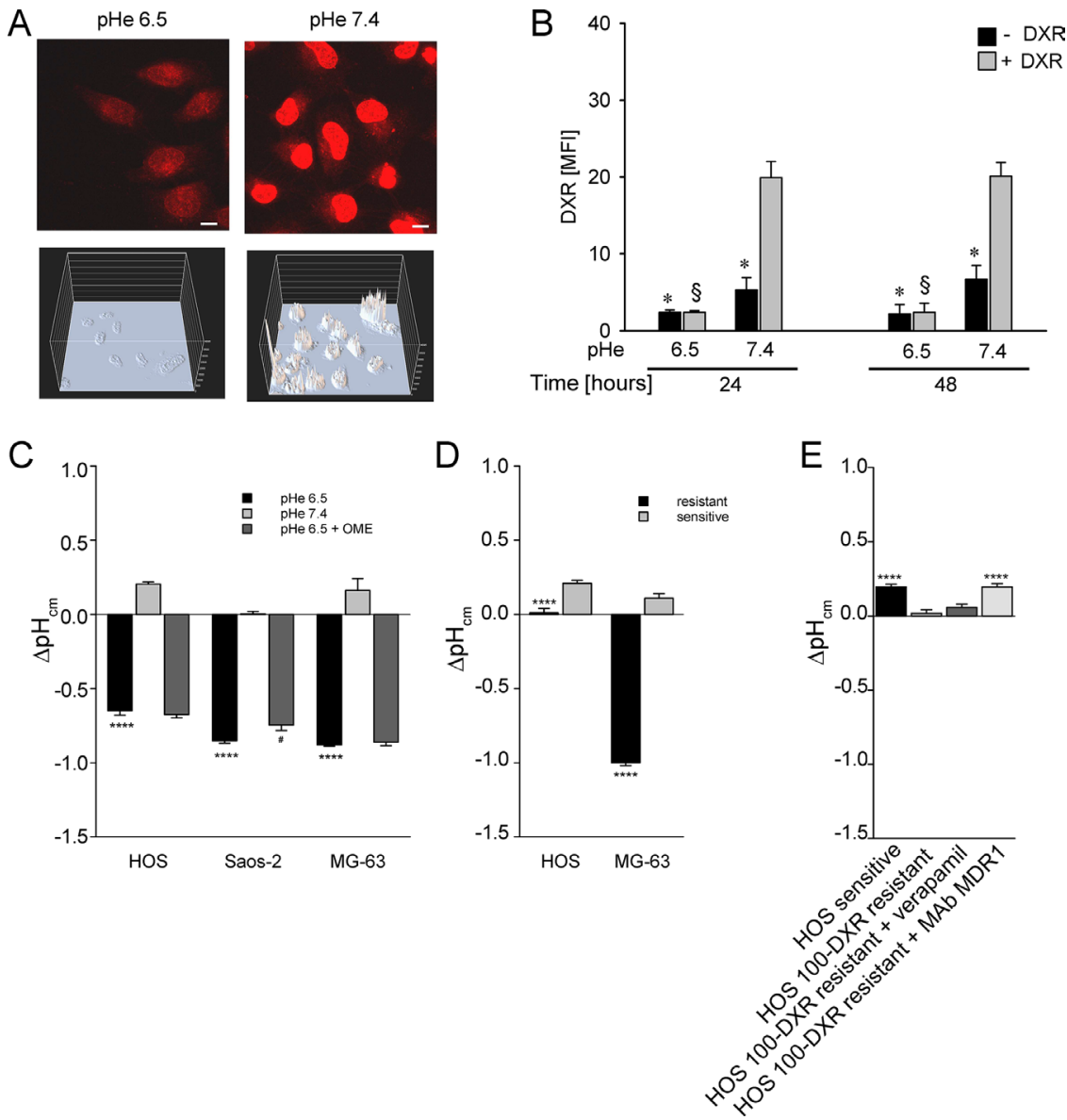

Figure 5: Total DXR concentration in HOS cells under acidity is reduced due to an increased $\mathrm{pH}$ gradient $(\Delta \mathrm{pHcm})$ at the plasma membrane. (A) 3D intensity embossed and confocal acquisition of DXR fluorescence in the DXR intracellular uptake assay by NIS Element software (Nikon) in HOS cells cultured under different $\mathrm{pH}$, representative image (scale bar $=10 \mu \mathrm{m}) ;(\mathbf{B})$ cytofluorimetric quantification of DXR uptake in HOS cells cultured under different $\mathrm{pHe}\left({ }^{*} p<0.05\right.$ not treated vs the DXR treated, at the same $\mathrm{pHe} ;{ }^{\S} p<0.05$ DXR treated at $\mathrm{pHe} 6.5$ vs the DXR treated at $\mathrm{pH} 7.4$ ). MFI, Mean Fluorescence Intensity. (C) $\Delta \mathrm{pH}_{\mathrm{cm}}$ plasma membrane gradient by SNARF staining of live cells cultured under acidic conditions, treated or not treated with OME, and measured by spectral confocal microscopy $\left(* * * * p<0.0001\right.$ vs pHe 7.4, ${ }^{*} p<0.05$ vs pHe 6.5, $n=12$ ). The uncharged SNARF-1-AM can passively diffuse across the plasma membrane to cytosol, where it hydrolyzed by cellular esterases to free SNARF-1. It is this form that is fluorescent, and is consequently the intracellular $\mathrm{pH}$ probe. Intracellular $\mathrm{pH}$ measurement and $\mathrm{pH}$ calibration using single excitation-dual emission fluorescence ratios were performed as described in the method paragraph; (D) $\Delta \mathrm{pH}_{\mathrm{cm}}$ plasma membrane gradient by SNARF staining of live resistant cells cultured at $\mathrm{pHe} 7.4$ and that express P-gp protein $(* * * * p<0.0001 \mathrm{vs}$ sensitive cultured at $\mathrm{pHe} 7.4, n=12) ;(\mathbf{E}) \Delta \mathrm{pH}_{\mathrm{cm}}$ plasma membrane gradient by SNARF staining of live HOS resistant cells (HOS 100-DXR), cultured at pHe 7.4, and treated or not treated with verapamil or with a monoclonal blocking antibody against MDR-1 (****p $<0.0001$ vs resistant cells). 
OME on DXR sensitivity, both in vitro and in vivo. After pretreatment with OME, the growth inhibition of DXR was significantly increased. The combination of OME with DXR induced a growth rate reduction at a 10 -fold lower concentration of DXR. In the xenograft model of OS, when combined with OME, treatment with DXR produced a significant reduction of tumor volume and an increase of necrosis. Most importantly, these effects were obtained with a low concentration $(1.5 \mathrm{mg} / \mathrm{kg})$ of DXR with respect to the dosage commonly used in OS xenografts $(2.5 \mathrm{mg} / \mathrm{kg})$ [50]. DXR as a single treatment at the same concentration did not produce any effect. Such concentration was calculated as $1 / 6$ of the minimum dose used for a therapeutic regimen in human patients (60-90 mg/ $\mathrm{m}^{2}$, corresponding to $9-14 \mathrm{mg} / \mathrm{kg}$ in a child of $24 \mathrm{~kg}$, with a height of $120 \mathrm{~cm}$ ) [1]. The combined treatment also had a positive impact on the systemic toxicity associated with DXR treatment. In fact, mouse body weight was less affected with respect to DXR alone both at $1.5 \mathrm{mg} / \mathrm{kg}$ and $2.5 \mathrm{mg} / \mathrm{kg}$ (data not shown).

In summary, the reduced toxicity of DXR in OS sensitive (P-gp negative) cells under low $\mathrm{pHe}$ was independent of autophagy but apparently associated with
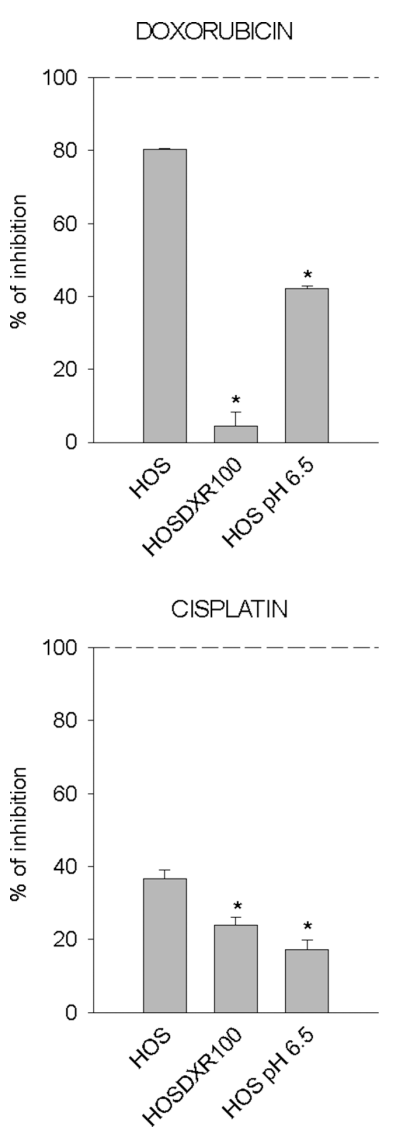

an increased lysosomal acidification. Notably, this type of resistance develops within hours, in contrast to the expression of P-gp that occurs, according to the canonical model of MDR, after months of continuous exposure to DXR. To verify that resistance to DXR under short-term exposure to acidity is actually due to drug accumulation into lysosomes, we observed the intracellular fluorescence of DXR after 5-10 min of incubation. Surprisingly, DXR did not accumulate into the cell, a minor portion being compartmentalized into lysosomes. The high $\mathrm{pH}$ gradient generated between the acidic extracellular compartment and the alkaline cytosolic space is sufficient to affect the permeability to weak cationic drugs at the plasma membrane [51]. This occurs because uncharged, organic free bases are more permeable than their protonated charged counterparts and establish equal concentrations on both sides of the membrane. We therefore measured the difference between the extracellular and the cytosolic $\mathrm{pH}\left(\mathrm{pHe}-\mathrm{pHi}, \Delta \mathrm{pH}_{\mathrm{cm}}\right)$ at different $\mathrm{pHe}$. Although the $\mathrm{pHi}$ was mildly acidified by the extracellular milieu, the net result was a strong alteration of $\Delta \mathrm{pH}_{\mathrm{cm}}$ with a reversal of net charges. Notably, in Saos-2 cells, pre-treatment with OME slightly reduced this trend. Only a few reports have
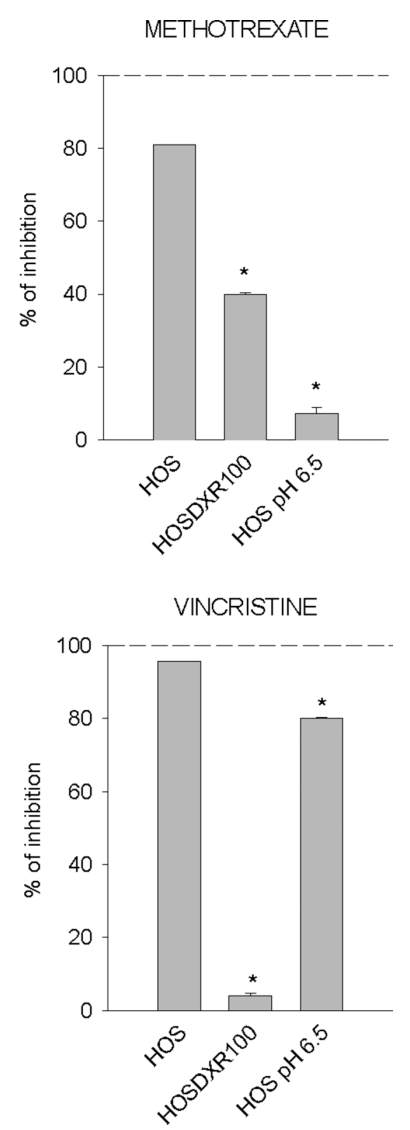

Figure 6: Chemoresistant phenotypes of OS cells cultured at different pHe and treated with different drugs. Percentage of inhibition of cell viability of HOS cells cultured at pH 7.4, of P-gp expressing HOS cells (HOS 100-DXR), and of HOS cells cultured at $\mathrm{pH} 6.5$ treated with different drugs, as measured by acid phosphatase assay after $72 \mathrm{~h}\left({ }^{*} p<0.05\right.$ vs HOS cells cultured at $\mathrm{pH} 7.4$ and treated with the respective drug). 
linked pHi regulation also to drug resistance mediated by P-gp expression. MDR cells have been reported to have a more alkaline $\mathrm{pHi}[32,52]$, and the magnitude of plasma membrane electrical potential decreases along with the increase of expression of P-gp [53]. According to this hypothesis, P-gp-mediated effects depend also on an altered regulation of ion transporters and signal transduction pathways (i.e., $\mathrm{pH}$ and membrane potential, key features necessary for the correct setting the biophysical parameters of the cells) [54]. In this context, P-gp has been suggested to work as a chloride channel, although it is yet unclear whether it might physically form a channel-like structure or rather regulate nearby anion transporters involved in the maintenance of $\mathrm{pHi}[53,55,56]$. Here, we confirmed that P-gp expression in P-gp overexpressing OS cells obtained by continuous exposure to DXR [5] induces an alteration of $\Delta \mathrm{pH}_{\mathrm{cm}}$, that is partially reverted by verapamil. Moreover, we further verified that the anti P-gp monoclonal antibody MRK16, known to revert the MDR phenotype [57] completely abolished the $\Delta \mathrm{pH}_{\mathrm{cm}}$ decrease observed under acidity. Therefore, according to our data, a change in $\Delta \mathrm{pH}_{\mathrm{cm}}$ is necessary to induce chemoresistance, either by shortterm acidosis or by the long term drug exposure leading to P-gp expression. On this regard, the reversed $\Delta \mathrm{pH}_{\mathrm{cm}}$ has been recently shown to interfere with the passage of drugs across the lipid bilayer of the cells, by altering the fluidity, the relative lipid density, and the surface tension of each of the leaflets within the membrane [33]. Short-term acidosis induced chemoresistance not only to DXR, but also to methotrexate, vincristine and, at a lesser extent, to cisplatin, other drugs commonly included in the standard therapeutic protocol for OS.

\section{Concluding remarks}

Altogether, our data provide evidence that the chemoresistant phenotype of OS is dependent on an inverted or altered $\Delta \mathrm{pH}_{\mathrm{cm}}$. This might rapidly result from the acidification of the TME (Figure 7B), or derive from the induction of the expression of P-gp (Figure 7C). In this view, buffer therapies or proton pump inhibitors that block the abnormal $\Delta \mathrm{pH}_{\mathrm{cm}}$ could be used in combination with standard anticancer agents. This hypothesis is supported by the encouraging results obtained in a pilot clinical study of human OS by the addition of esomeprazole to standard chemotherapy regimens [58]. Finally, the consistent evidence that changes of pHe strongly impact on the cytotoxicity of anticancer drugs should be taken into account. We therefore propose that in vitro IC50 assays for anticancer agents in sarcomas should always include a condition with an acidic medium in the range of $\mathrm{pH} 6.5$ 6.8 to mimic the actual conditions of TME.

\section{MATERIALS AND METHODS}

\section{Cell lines}

HOS, Saos-2, MG-63, and 143B human OS cell lines were purchased from the American Type Culture Collection, cultured in RPMI plus 20 units $/ \mathrm{mL}$ penicillin, $100 \mu \mathrm{g} / \mathrm{mL}$ streptomycin, and $10 \%$ FCS at $\mathrm{pH} 7.4$ (complete medium), and incubated at $37^{\circ} \mathrm{C}$ in a humidified $5 \% \mathrm{CO}_{2}$ atmosphere. In assays with different $\mathrm{pH}$, cells were seeded in complete medium, and after $24 \mathrm{~h}$ media were changed. New media were set at a specific $\mathrm{pH}$ by
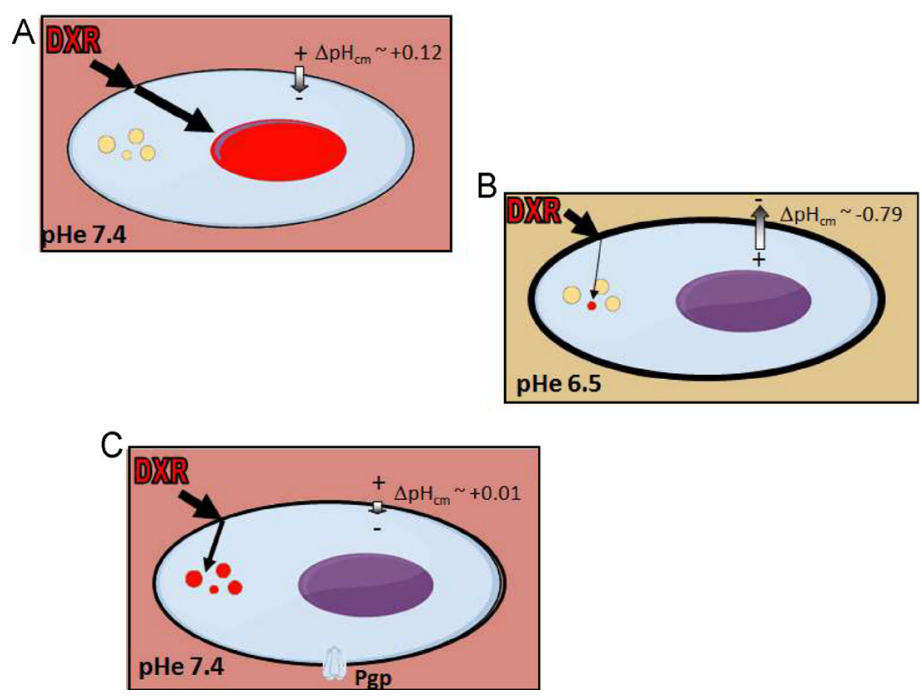

Figure 7: $\Delta \mathrm{pH}_{\mathrm{cm}}$ at the plasma membrane is an important player in OS chemoresistance. (A) When OS cells growth in a microenvironment with pHe 7.4 and with an unaffected system to maintain the pHi, DXR accumulates into the nucleus; (B) when OS cells growth in a microenvironment with $\mathrm{pHe}$ around 6.5, the $\Delta \mathrm{pH}_{\mathrm{cm}}$ is reverted and DXR does enter into the cell. Only a very small fraction of DXR reaches the cytoplasm, and is immediately sequestered into lysosomes that, under this condition, are even more acidic; (C) when OS cells growth in a microenvironment with pHe 7.4 and express Pgp, the system to maintain the pHi is altered, membrane potential is reduced, and lysosomes are more acidic. As a result, although DXR can reach the cytoplasm, it is immediately sequestered into lysosomes. 
using different concentrations of sodium bicarbonate needed to preset $\mathrm{pH}$ in $5 \% \mathrm{CO}_{2}$ atmosphere, according to the Henderson-Hasselbach equation. At the end-point of each experiment, the final $\mathrm{pH}$ in the supernatant was always measured by a digital $\mathrm{pH}-$ meter $(\mathrm{pH} 301$, HANNA Instruments). To obtain HOS 100-DXR cells and MG-63 MDR cells we continuously exposed parental cell lines to stepwise increases in DXR concentration (10-30-100 $\mathrm{ng} / \mathrm{mL}$ for HOS and 10-30 ng/mL for MG-63, Sigma). Approximately 2-3 weeks (4-5 passages) were required to establish adequate growth at each DXR concentration.

\section{Growth assays}

Cells were seeded in 6-well plates $(100,000$ cells/ well) in complete medium. After $24 \mathrm{~h}$, the medium was changed with new complete medium at different $\mathrm{pH}$, or with complete medium without sodium bicarbonate (unbuffered medium, UB), with or w/o DXR (15 ng/mL). The $\mathrm{pH}$ in UB condition, measured at all time points and for each cell line, was always $6.75 \pm 0.07$. Cell growth was evaluated by direct cell counting using the eritrosin dye (Sigma). Growth inhibition was obtained in respect to the untreated condition at the respective $\mathrm{pH}$, and at a time point just after the specific doubling time at the considered $\mathrm{pH}$ (for HOS: $24 \mathrm{~h}$ at $\mathrm{pH} 7.4$ and 8, $48 \mathrm{~h}$ at $\mathrm{pH} 6.5$ and 6.75; for Saos-2: $48 \mathrm{~h}$ at all the $\mathrm{pH}$; for MG-63: $42 \mathrm{~h}$ at $\mathrm{pH}$ 7.4 and 8 , and $72 \mathrm{~h}$ at $\mathrm{pH} 6.5$ and 6.75). The experiments were repeated three times, with two replicates for each assay.

To calculate the IC50 values for DXR or to evaluate the growth inhibition of DXR treatment combined with pre-treatment with the proton-pump inhibitor omeprazole (OME), cells were seeded in 96-well plates $(4,000$ cells/ well) in complete medium. After $24 \mathrm{~h}$, the medium was changed with new medium at different $\mathrm{pH}$, with or w/o DXR (0-10-30-100-1000 $\mathrm{ng} / \mathrm{mL}$ ). For the combined treatment, $2 \mathrm{~h}$ before the change of media with DXR, cells were washed with PBS and incubated with medium 0.1 $\%$ FCS with or w/o OME (210 $\mu \mathrm{M}$, Sigma). After $72 \mathrm{~h}$ since the addition of DXR, the cell number was measured by an acid phosphatase assay, as previously described [59]. Briefly, the culture medium was removed, wells were washed with PBS, and $100 \mu \mathrm{l}$ of buffer containing $0.1 \mathrm{M}$ sodium acetate ( $\mathrm{pH}$ 5.0), $0.1 \%$ Triton $\mathrm{X}-100$, and $5 \mathrm{mM}$ p-nitrophenil phosphate (Sigma) was added. After $3 \mathrm{~h}$ at $37^{\circ} \mathrm{C}$, the reaction was stopped with the addition of $10 \mu \mathrm{l}$ of a $1 \mathrm{~N} \mathrm{NaOH}$, and color development was assayed at $405 \mathrm{~nm}$ using a microplate reader (Tecan Infinite F200pro). The experiment was repeated twice in quadruplicate.

Similarly, to evaluate the percentage of inhibition of viability, cells were seeded in complete medium, and after additional $24 \mathrm{~h}$, the medium was replaced with the respective conditions added with DXR $100 \mathrm{ng} / \mathrm{mL}$, or Cysplatin $250 \mathrm{ng} / \mathrm{mL}$, or Methotrexate
$10 \mathrm{ng} / \mathrm{mL}$, or Vincristine $100 \mathrm{ng} / \mathrm{mL}$. After $72 \mathrm{~h}$ the cell number was measured by an acid phosphatase assay as described above. The experiment was repeated twice in quadruplicate.

\section{DXR uptake}

According to the previously described method [60], cells were seeded at low density in a glass-bottom Petri dish (Inco), and incubated for $48 \mathrm{~h}$ in complete medium at different $\mathrm{pH}$. Then, the medium was changed at the respective $\mathrm{pH}$ with DXR $10 \mu \mathrm{g} / \mathrm{mL}$ for 5 or $15 \mathrm{~min}$. Cells were washed with PBS and maintained with drug-free complete medium at the respective $\mathrm{pH}$. For quantitative determination of intranuclear DXR concentration, the laser (Exc wavelength $457.9 \mathrm{~nm}$ ) was focused for $1 \mathrm{sec}$ with a pinhole of $54 \mu \mathrm{m}$ to the nucleus of cells to obtain fluorescence emission spectra. The drug concentration in the nuclei of living cells were obtained from the specific spectra contribution of DXR (Emi 560-590 nm). The analysis was performed using a TiE spectral confocal laser microscope (A1R, Nikon) equipped with a DS-QIMc-U2 12 bit camera. We measured the fluorescence of 25 nuclei (within the nuclear perimeter) of 5 different random optical fields. DXR nuclear uptake was expressed as the mean of the sum of intensities divided by the nuclear area. The same experimental conditions and settings for confocal microscopy were also used for the acquisition of $3 \mathrm{D}$ intensity embossed images.

\section{Western blotting}

HOS cells were seeded in complete medium. After $24 \mathrm{~h}$ the medium was changed with new medium at different $\mathrm{pH}$ with or w/o DXR $(10-100 \mathrm{mg} / \mathrm{mL})$ for 1 month to determine the level of P-gp expression. The medium was changed every 3-4 d, and confluent cells were trypsinized. Cells were treated in ice with 400 of lysis buffer [50 mM HEPES ( $\mathrm{pH} 7.5$ ), $150 \mathrm{mM} \mathrm{NaCl}, 1.5 \mathrm{~mm}$ $\mathrm{MgCl} 2,1 \mathrm{mM}$ EGTA, 10\% glycerol, $1 \%$ Triton X-100, 1\% PMSF, $0.2 \mathrm{mM} \mathrm{Na}$ orthovanadate and $1 \%$ aprotinin, all from Sigma]. Protein concentration was determined with the Bradford protein assay (Bio-Rad). Total protein was separated on $6 \%$ gradient SDS-PAGE gel and transferred into nitrocellulose membranes. Blots were blocked with 5\% nonfat dry milk in TBST and probed with the monoclonal P-gp (clone D-11), or TATA binding protein (TBP) rabbit antibodies (Santa Cruz Biotechnology). The secondary antibody was an anti-rabbit or anti-mouse $\operatorname{IgG}$ conjugated to horseradish peroxidase that was visualized by enhanced chemiluminescence detection reagents (Pierce). For the analysis of autophagy flux in HOS cells, PVDF membranes (GE Healthcare) were used and incubated with the following antibodies: rabbit polyclonal LC3B (Cell Signaling Technology), monoclonal $\beta$-actin (ACTB, clone AC-15) (Sigma), rabbit polyclonal ATG5 
(Cell Signaling Technology), monoclonal SQSMT1 (clone 3/P62 LCK LIGAND, BD Transduction laboratories), and rabbit DNA binding protein high mobility group box 1 (HMGB1) (Cell Signaling Technology) antibodies.

\section{Ultrastructural analysis}

HOS cells cultured under acidic $(\mathrm{pH} 6.5)$ or standard $(\mathrm{pH} 7.4)$ conditions were washed in PBS and fixed with $2.5 \%$ glutaraldehyde in $0.1 \mathrm{M}$ cacodylate buffer $\mathrm{pH}$ 7.4 (Sigma) for $30 \mathrm{~min}$ at $\mathrm{R}^{\circ} \mathrm{T}$, scraped, and pelletted at $1,300 \mathrm{~g}$ for $20 \mathrm{~min}$. Pellets were further fixed for $2 \mathrm{~h}$. After washing in $0.1 \mathrm{M}$ cacodylate buffer, samples were post-fixed with $1 \%$ osmium tetroxide in cacodylate buffer (Sigma) for $1 \mathrm{~h}$ at $4{ }^{\circ} \mathrm{C}$, dehydrated, and embedded in Epon resin. Ultrathin sections were stained with tannic acid, uranyl acetate and lead citrate, and observed with a Zeiss EM 109 transmission electron microscope. Image were captured using a Nikon digital camera (Dmx 1200F) and the ACT-1 software.

\section{Lysosomal pH assays}

Cells were cultured in complete medium at different $\mathrm{pH}$ for $48 \mathrm{~h}$ and then analyzed. Lysosensor staining: labeling and tracking of acidic organelles in living cells was performed by incubation with $1 \mu \mathrm{M}$ LysoSensor Green DND-189 and 50 nM LysoTracker Red DND-99 (Molecular Probes, Life Technologies) in medium at the respective $\mathrm{pH}$. After $30 \mathrm{~min}$ at $37^{\circ} \mathrm{C}$, cells were washed with fresh medium and observed by confocal microscopy (Nikon Eclipse E600).

Confocal spectral analysis: the emission spectra of the $\mathrm{pH}$-sensitive dye $\mathrm{AO}$ was used to measure $\mathrm{pH}$ variations in acidic organelles, as previously described [61]. MG-63 cells were incubated with AO $(0.5 \mu \mathrm{g} / \mathrm{mL}$, Sigma) in medium at the respective $\mathrm{pH}$ for $15 \mathrm{~min}$. After washing, $\mathrm{x}, \mathrm{y}$ emission spectra from confocal sections of single living cells were recorded using a confocal laser microspectrofluorimeter (Nikon, TI) equipped with an argon-ion laser. Cells were focused with a $\times 40,1.3 \mathrm{NA}$ objective (S Fluor, Nikon), excited at $457 \mathrm{~nm}$ and the resulting fluorescence emission in the 500-700 $\mathrm{nm}$ range was collected. For intracellular measurements of AO emission the pinhole size was fixed to a diameter of 54 $\mu \mathrm{m}$. To characterize the profile of AO emission spectra, the red band contribution ( $\mathrm{R} \%$ ) within the whole emission spectrum was calculated as follows: $\mathrm{R} \%=100 * \mathrm{I}_{655} /\left(\mathrm{I}_{655}\right.$ $\left.+\mathrm{I}_{530}\right)$ where $\mathrm{I}_{655}$ and $\mathrm{I}_{530}$ are the green (520-540 nm) and the red (645-665 nm) integrated emission intensities, respectively. The $\mathrm{R} \%$ was calculated for all the lysosomes within a single cell, and the average $\mathrm{R} \%$ of lysosomes of single cells was considered. Average of the total number of all the lysosomes per single cell that were detectable by confocal microscopy analysis and AO staining was calculated out of 20 cells.

\section{RNA extraction and RNA sequence analysis}

Total RNA was extracted using guanidinium thiocyanate-phenol-chloroform from cell cultured under acidic $(\mathrm{pH}$ 6.5) or standard conditions $(\mathrm{pH} 7.4)$ for $24 \mathrm{~h}$, and quantified by Bioanalyzer (Agilent, Santa Clara, CA) following the manufacturer's instructions. RIN (RNA Integrity Number) and A260/A280 ratio of the prepared total RNA were all 10, and over 1.8, respectively. The library of template molecules for high throughput DNA sequencing was converted from the total RNA using TruSeq RNA Sample Prep Kit v2 (Illumina) following the manufacturer's protocol. The library was quantified with Bioanalyzer (Agilent) following the manufacturer's instruction. Library (7 pM) was subjected to cluster amplification to cluster generation on a Single Read Flow Cell v4 with a cluster generation instrument (Illumina). Sequencing was performed on a Genome Analyzer GAIIx for 76 cycles using Cycle Sequencing v4 regents (Illumina). Image analysis and base calling were performed using Off-Line Basecaller Software 1.6 (Illumina). Reads were aligned using ELAND v2 of CASAVA Software 1.7 with the sequence data sets. Human genome build 19 (hg19) were downloaded from University of California, Santa Cruz genome browser (http://genome. ucsc.edu/) as the analytic reference. Transcript coverage for every gene locus was calculated from the total number passing filter reads that mapped, by ELAND-RNA, to exons. These analyses were performed using default parameters. The advanced analysis for quantification with Quantile normalization algorithm was performed using Avadis NGS software (version1.5, Strand Scientific Intelligence Inc.). Filtering was performed using default parameters. All new data were deposited in DDBJ/EMBL/ GenBank under accession number DRA DRA004087.

\section{Immunofluorescence}

Before fixation, cells were incubated for $24 \mathrm{~h}$ at different $\mathrm{pH}$, and then incubated with Lysotracker $(0.25 \mu \mathrm{M})$ in medium at the respective $\mathrm{pH}$ for $30 \mathrm{~min}$ at $37^{\circ} \mathrm{C}$. Cells were washed with $\mathrm{PBS}$, fixed in $3 \%$ paraformaldehyde in PBS containing $300 \mathrm{mM}$ sucrose (Sigma) for $20 \mathrm{~min}$ at $22^{\circ} \mathrm{C}$. After washing with PBS, permeabilization was performed with $0.1 \%$ Triton $\mathrm{X}-100$ for $5 \mathrm{~min}$. Then, cells were incubated with the anti-LC3B antibody (Santa Cruz Biotechnology), and with a solution containing anti-mouse Alexa green $488 \mathrm{~nm}$ (Molecular Probes, Life Technologies), and Hoechst 33258 (1.25 $\mu \mathrm{g} / \mathrm{mL}$, Sigma) for the nuclear staining, and observed by confocal microscopy (Nikon TI-E). The staining was repeated two times.

\section{Analysis of the autophagic flux}

HOS cells were seeded at 200,000 cells/plate in $6 \mathrm{~cm}$ tissue cultures dishes in standard RPMI medium. 
After overnight incubation the medium was replaced with medium buffered at $\mathrm{pH} 7.4$ or at $\mathrm{pH} 6.5$ and cells were collected at different time points $(4,8,24$ and $48 \mathrm{~h})$ after exposure to fresh media. For each time point, cells were treated or not with $50 \mathrm{nM}$ bafilomycin A1 (BafA1) for $2 \mathrm{~h}$ before collection. In some experiments, the lysosomal inhibitors pepstatin A and E64d were used at $10 \mathrm{mg} /$ $\mathrm{ml}$. Analysis of the effects of DXR where performed by adding the drug $(100 \mathrm{nM})$ for $24 \mathrm{~h}$ in the presence or absence of BafA1. The use of BafA1 to block lysosomal acidification was performed in order to analyze the rate of LC3 and SQTM1 degradation, indicative of the autophagic flux [36].

\section{ATG5 silencing}

HOS cells were seeded in 6-wells plates $(50,000$ cells/well) in medium without antibiotics. The next day, cells were transfected with $25 \mathrm{nM}$ siRNA for ATG5 (Dharmacon RNA Technologies siGENOME SMART pool) and siRNA SCR (scrambled siRNA, control) using DharmaFECT-4 transfection reagent (Dharmacon), following the manufacturer's instructions. The next day, the medium was changed with fresh complete medium buffered at different $\mathrm{pH}$ (7.4 and 6.5), with or without DXR (100 ng/mL). After $36 \mathrm{~h}$, cells were collected and analyzed for apoptosis by Annexin V staining. Cells for Western blot analysis were collected at the same time. Four replicates were made for each assay.

\section{Apoptosis assay}

We evaluated apoptotic cell death by using Annexin-V staining (FITC Annexin V Apoptosis Detection Kit, BD Pharmingen) and by collecting green fluorescence in a FACSCalibur flow cytometer (Becton Dickinson) using the Cellquest Pro software. At least 10,000 cells/ sample were acquired and analyzed. The experiments were repeated five times, with two replicates for each assay.

\section{In vivo studies}

NOD/SCID animals were housed and maintained in a pathogen-free environment. 143B human cells $\left(1 \times 10^{6}\right)$ were subcutaneously injected with the reduced growth factor matrigel (BD, Bioscience) in the flank of 5 weeks old male mice (Charles River Laboratories International). Four days after the inoculation, mice were randomly separated into groups and assigned to pharmacological treatments (for each group $n=7$ ). Both OME and DXR were reconstituted in saline solution and injected intraperitoneally (10 mg/kg and $1.5 \mathrm{mg} / \mathrm{kg}$, respectively). Mice received saline solution, OME, DXR or a combination of OME and DXR, the latter being injected $2 \mathrm{~h}$ after OME treatment. Weights were taken daily during treatment, and drug concentrations were recalculated to ensure that mice received a constant dose of OME and DXR. Treatments were repeated every 4 days and mice were sacrificed 18 days after tumor inoculation. Tumor size was estimated at every pharmacological treatment with a caliper and the weight was calculated by using the formula: tumor volume $\left[\mathrm{mm}^{3}\right]=\left(\right.$ length $[\mathrm{mm}] \times$ width $^{2}$ $\left.\left[\mathrm{mm}^{2}\right]\right) / 2$ [62]. For histological analysis, tumor xenografts were fixed in formalin and embedded in paraffin. $5 \mu \mathrm{m}$ sections were stained with hematoxylin/eosin. The area of necrosis was quantified by NIS element image analysis software (Nikon). The Animal Ethics Committee of Modena has approved all the experimental protocols.

\section{DXR intracellular content by flow cytometry quantification}

HOS cells were seeded in 6-well plates $(50,000$ cells/well) in complete medium. The next day, the medium was changed with fresh medium buffered at different $\mathrm{pH}$ (7.4 and 6.5), with or w/o DXR (50 ng/mL). After 24 and $48 \mathrm{~h}$, cells were collected and at least 10,000 cells/sample were analyzed by flow citometry. The mean fluorescence intensity (MFI) in the FL2 channel was evaluated by the DXR red fluorescence.

\section{pH gradient at the plasma membrane}

Cytosolic intracellular $\mathrm{pH}(\mathrm{pHi})$ of OS cells was measured by using carboxy-SNARF-1 and confocal microspectrofluorometry (Nikon, TI). Cells were seeded into glass Petri dishes and incubated for $48 \mathrm{~h}$ in medium at different $\mathrm{pH}$. At the end, cells were additionally incubated in acidic $\mathrm{pH}$ ( $\mathrm{pH}$ 6.5) for HOS, Saos-2, and MG-63 cells or in complete medium for HOS 100-DXR cells, with OME $(210 \mathrm{mM})$ and Verapamil $(500 \mu \mathrm{M})$, single treatment or combined, or with the MRK16 anti-MDR-1 antibody $(10 \mathrm{~m} / \mathrm{mL})$. At the time of the analysis, cells were then treated with medium at the respective $\mathrm{pH}$ containing $10 \mu \mathrm{M}$ carboxy-SNARF-1 of the acetoxymethyl ester form (Molecular Probes, Life Technologies) at $37^{\circ} \mathrm{C}$ with $5 \% \mathrm{CO}_{2}$ for $30 \mathrm{~min}$. Medium was replaced again with medium at the respective $\mathrm{pH}$ and Petri dishes were placed in an incubator (OkoLab), on the stage of the confocal microscope. We used an excitation laser of $514 \mathrm{~nm}$ wavelength (Argon) and a S Plan Fluor ELWD 40X lend (Nikon). The resulting fluorescence emissions at $644 \mathrm{~nm}$ and at $594 \mathrm{~nm}$ wavelengths were collected. Several regions of interest (ROI) were then randomly selected excluding nuclear regions. The emission ratio was calibrated using solutions (110 mM KCl, $25 \mathrm{mM} \mathrm{KHCO3,} 11 \mathrm{mM}$ glucose, $1 \mathrm{mM} \mathrm{MgCl2}, 1 \mathrm{mM} \mathrm{CaCl2}, 10 \mathrm{mM}$ HEPES, Sigma) with varying $\mathrm{pH}(\mathrm{pH} 6.5-8.0)$ that contained $10 \mu \mathrm{M}$ nigericin $\left(\mathrm{K}^{+} / \mathrm{H}^{+}\right.$ionophore, Sigma). In this case, cells were allowed to adapt for at least $20 \mathrm{~min}$ before $\mathrm{pHi}$ measurements began. The fluorescence emission ratio $(644 \mathrm{~nm} / 594 \mathrm{~nm})$ was calculated and used to estimate cytoplasmic $\mathrm{pH}$ from 
the calibration curve of each cell line. Confocal images were processed using NIS Elements software (Nikon). We quantified 12 different random cells for each condition.

\section{Statistical analysis}

Due to the small number of observations, data were considered as not normally distributed. Values were expressed as means \pm SE. Statistical analysis was performed with the StatView 5.0.1 software (SAS Institute Inc., Cary, NC). The nonparametric Mann-Whitney $U$ test was used and $p<0.05$ was considered significant.

\section{Abbreviations}

Osteosarcoma (OS); doxorubicin (DXR); P-glycoprotein (P-gp); tumor microenvironment (TME); hypoxia-inducible factor- $1 \alpha$ (HIF-1 $\alpha)$; extracellular $\mathrm{pH}$ (pHe); multidrug resistance (MDR); intracellular $\mathrm{pH}$ (pHi); $\mathrm{pH}$ gradient at the cytoplasmic membrane $\left(\Delta \mathrm{pH}_{\mathrm{cm}}\right)$; unbuffered medium (UB); omeprazole (OME); TATA binding protein (TBP); DNA binding protein high mobility group box 1 (HMGB1); acridine orange (AO); bafilomycin A1 (BafA1);

\section{CONFLICTS OF INTEREST}

Authors have no other potential conflicts of interest.

\section{GRANT SUPPORT}

Italian Association for Cancer Research (grant No. 11426 and 15608 to N.B.), financial support for Scientific Research "5 per 1000 2012" (to N.B.), and Swedish Cancer Society (grant \# CAN 2012/415 to A.D.).

\section{REFERENCES}

1. Luetke A, Meyers PA, Lewis I, Juergens H. Osteosarcoma treatment - where do we stand? A state of the art review. Cancer Treat Rev. 2014; 40:523-532.

2. Chou AJ, Gorlick R. Chemotherapy resistance in osteosarcoma: current challanges and future directions. Expert Rev Anicancer Ther. 2006; 6:1075-1085.

3. Baldini N, Scotlandi K, Barbanti-Brodano G, Manara MC, Maurici D, Bacci G, Bertoni F, Picci P, Sottili S, Campanacci M, Serra M. Expression of p-glycoprotein in high-grade osteosarcomas in relation to clinical outcome. N Engl J Med. 1995; 333:1380-1385.

4. Baldini N. Multidrug resistance--a multiplex phenomenon. Nat Med. 1997; 3:1380-1385.

5. Scotlandi K, Benini S, Sarti M, Serra M, Lollini PL, Maurici D, Picci P, Manara MC, Baldini N. Insulinlike growth factor i receptor-mediated circuit in ewing's sarcoma/peripheral neuroectodermal tumor: A possible therapeutic target. Cancer Res. 1996; 56:4570-4574.
6. Serra M, Scotlandi K, Manara MC, Maurici D, Benini S, Sarti M, Campanacci M, Baldini N. Analysis of P-glycoprotein expression in osteosarcoma. Eur J Cancer. 1995; 31A:1998-2002.

7. Ferrari S, Bertoni F, Zanella L, Setola E, Bacchini P, Alberghini M, Versari M, Bacci G. Evaluation of p-glycoprotein, her-2/erbb-2, p53, and bcl-2 in primary tumor and metachronous lung metastases in patients with high-grade osteosarcoma. Cancer. 2004; 100:1936-1942.

8. Zhao Y, Zhang CL, Zeng BF, Wu XS, Gao TT, Oda Y. Enhanced chemosensitivity of drug-resistant osteosarcoma cells by lentivirus-mediated bcl-2 silencing. Biochem Biophys Res Commun. 2009; 390:642-647.

9. Song B, Wang Y, Xi Y, Kudo K, Bruheim S, Botchkina GI, Gavin E, Wan Y, Formentini A, Kornmann M, Fodstad O, $\mathrm{Ju}$ J. Mechanism of chemoresistance mediated by mir-140 in human osteosarcoma and colon cancer cells. Oncogene. 2009; 28:4065-4074.

10. Song B, Wang Y, Titmus MA, Botchkina G, Formentini A, Kornmann $\mathrm{M}, \mathrm{Ju} \mathrm{J}$. Molecular mechanism of chemoresistance by mir-215 in osteosarcoma and colon cancer cells. Mol Cancer. 2010; 9:96.

11. Santamaria-Martinez A, Huelsken J. The niche under siege: Novel targets for metastasis therapy. J Intern Med. 2013; 274:127-136.

12. Kaplan RN, Riba RD, Zacharoulis S, Bramley AH, Vincent L, Costa C, MacDonald DD, Jin DK, Shido K, Kerns SA, Zhu Z, Hicklin D, Wu Y, et al. Vegfr1-positive haematopoietic bone marrow progenitors initiate the premetastatic niche. Nature. 2005; 438:820-827.

13. Wong CC, Gilkes DM, Zhang H, Chen J, Wei H, Chaturvedi P, Fraley SI, Wong CM, Khoo US, Ng IO, Wirtz D, Semenza GL. Hypoxia-inducible factor 1 is a master regulator of breast cancer metastatic niche formation. Proc Natl Acad Sci U S A. 2011; 108:16369-16374.

14. Erler JT, Bennewith KL, Cox TR, Lang G, Bird D, Koong A, Le QT, Giaccia AJ. Hypoxia-induced lysyl oxidase is a critical mediator of bone marrow cell recruitment to form the premetastatic niche. Cancer Cell. 2009; 15:35-44.

15. Mimeault M, Batra SK. Hypoxia-inducing factors as master regulators of stemness properties and altered metabolism of cancer- and metastasis-initiating cells. J Cell Mol Med. $2013 ; 17: 30-54$.

16. Selvendiran K, Bratasz A, Kuppusamy ML, Tazi MF, Rivera BK, Kuppusamy P. Hypoxia induces chemoresistance in ovarian cancer cells by activation of signal transducer and activator of transcription 3. Int $\mathbf{J}$ Cancer. 2009; 125:2198-2204.

17. Wouters A, Pauwels B, Lardon F, Vermorken JB. Review: implications of in vitro research on the effect of radiotherapy and chemotherapy under hypoxic conditions. Oncologist. 2007; 12:690-712.

18. Yang QC, Zeng BF, Dong Y, Shi ZM, Jiang ZM, Huang J. Overexpression of hypoxia-inducible factor-1alpha in 
human osteosarcoma: Correlation with clinicopathological parameters and survival outcome. Jpn J Clin Oncol. 2007; 37:127-134.

19. Mizobuchi H, Garcia-Castellano JM, Philip S, Healey JH, Gorlick R. Hypoxia markers in human osteosarcoma: An exploratory study. Clin Orthop Relat Res. 2008; 466:2052-2059.

20. Mohyeldin A, Grazon-Muvdi T, Quinones-Hinojosa A. Oxygen in stem cell biology: a critical component of stem cell niche. Cell Stem Cell. 2010; 7:150-161.

21. Rankin EB, Giaccia AJ, Schipani E. A central role for hypoxic signaling in cartilage, bone, and hematopoiesis. Curr Osteoporos Rep. 2011; 9:46-52.

22. Warburg O. On the origin of cancer cells. Science. 1956; 123:309-314.

23. Griffiths JR. Are cancer cells acidic? Br J Cancer. 1991; 64:425-427.

24. Vaupel P, Kallinowski F, Okunieff P. Blood flow, oxygen and nutrient supply, and metabolic microenvironment of human tumors: A review. Cancer Res. 1989; 49:6449-6465.

25. Engin K, Leeper DB, Cater JR, Thistlethwaite AJ, Tupchong L, McFarlane JD. Extracellular ph distribution in human tumours. Int J Hyperthermia. 1995; 11:211-216.

26. Lloyd MC, Cunningham JJ, Bui MM, Gillies RJ, Brown JS, Gatenby RA. Darwinian dynamics of intratumoral heterogeneity: Not solely random mutations but also variable environmental selection forces. Cancer Res. 2016; 76:3136-3144.

27. Peppicelli S, Bianchini F, Calorini L. Dynamic scenario of metabolic pathway adaptation in tumors and therapeutic approach. Oncoscience. 2015; 2:225-232. doi: 10.18632/ oncoscience.123.

28. Avnet S, Di Pompo G, Lemma S, Salerno M, Perut F, Bonuccelli G, Granchi D, Zini N, Baldini N. V-atpase is a candidate therapeutic target for ewing sarcoma. Biochim Biophys Acta. 2013; 1832:1105-1116.

29. Perut F, Avnet S, Fotia C, Baglio SR, Salerno M, Hosogi S, Kusuzaki K, Baldini N. V-atpase as an effective therapeutic target for sarcomas. Exp Cell Res. 2014; 320:21-32.

30. Mahoney BP, Raghunand N, Baggett B, Gillies RJ. Tumor acidity, ion trapping and chemotherapeutics. I. Acid ph affects the distribution of chemotherapeutic agents in vitro. Biochem Pharmacol. 2003; 66:1207-1218.

31. Tannock IF, Rotin D. Acid ph in tumors and its potential for therapeutic exploitation. Cancer Res. 1989; 49:4373-4384.

32. Altan N, Chen Y, Schindler M, Simon SM. Defective acidification in human breast tumor cells and implications for chemotherapy. J Exp Med. 1998; 187:1583-1598.

33. Daniel C, Bell C, Burton C, Harguindey S, Reshkin SJ, Rauch C. The role of proton dynamics in the development and maintenance of multidrug resistance in cancer. Biochim Biophys Acta. 2013; 1832:606-617.

34. Balgi AD, Diering GH, Donohue E, Lam KK, Fonseca BD, Zimmerman C, Numata M, Roberge M. Regulation of mtorc1 signaling by ph. PLoS One. 2011; 6:e21549.
35. Marino ML, Pellegrini P, Di Lernia G, DjavaheriMergny M, Brnjic S, Zhang X, Hagg M, Linder S, Fais S, Codogno P, De Milito A. Autophagy is a protective mechanism for human melanoma cells under acidic stress. J Biol Chem. 2012; 287:30664-30676.

36. Klionsky DJ, Abdalla FC, Abeliovich H, Abraham RT, Acevedo-Arozena A, Adeli K, Agholme L, Agnello M, Agostinis P, Aguirre-Ghiso JA, Ahn HJ, Ait-Mohamed O, Ait-Si-Ali S, et al. Guidelines for the use and interpretation of assays for monitoring autophagy. Autophagy. 2012; 8:445-544.

37. Huang J, Ni J, Liu K, Yu Y, Xie M, Kang R, Vernon P, Cao L, Tang D. Hmgb1 promotes drug resistance in osteosarcoma. Cancer Res. 2012; 72:230-238.

38. Salerno M, Avnet S, Bonucelli G, Hosogi S, Granch D, Baldini N. Impairment of lysosomal activity as a therapeutic modality targeting cancer stem cells of embyonal rhabdomyosarcoma cell line RD. PloS one. 2014; 9:e110340.

39. Gomes CM, van Paassen H, Romeo S, Welling MM, Feitsma RI, Abrunhosa AJ, Botelho MF, Hogendoorn PC, Pauwels E, Cleton-Jansen AM. Multidrug resistance mediated by $\mathrm{ABC}$ transporters in osteosarcoma cell lines: mRNA analysis and functional radiotracer studies. Nucl Med Biol. 2006; 33:831-840.

40. Breedveld PI, Pluim D, Cipriani G, Dahlhaus F, van Eijndhoven MA, de Wolf CJ, Kuil A, Beijnen JH, Scheffer GL, JAnsen G, Borst P, Schellens JH. The effect of low $\mathrm{pH}$ on breast cancer resistance protein (ABCG2)mediated trasnport of methotrexate, 7-hydroxymethotrexate, methotrexate diglutamate, folic acid, mitoxantrone, topotecan, and resevratrol in in vitro drug transport models. Mol Pharmacol. 2007; 71:240-249.

41 Juliano RL, Ling V. A surface glycoprotein modulating drug permeability in Chinese hamster ovary cell mutants. Biochim Biophys Acta. 1976; 455:152-162.

42. Wojtkowiak JW, Verduzco D, Schramm KJ, Gillies RJ. Drug resistance and cellular adaptation to tumor acidic $\mathrm{ph}$ microenvironment. Mol Pharm. 2011; 8:2032-2038.

43. Gillies RJ, Deamer DW. Intracellular ph changes during the cell cycle in tetrahymena. J Cell Physiol. 1979; 100:23-31.

44. Tewey KM, Rowe TC, Yang L, Halligan BD, Liu LF. Adriamycin-induced DNA damage mediated by mammalian DNA topoisomerase ii. Science. 1984; 226:466-468.

45. Raghunand N, Martinez-Zaguilan R, Wright SH, Gillies RJ. $\mathrm{Ph}$ and drug resistance. Ii. Turnover of acidic vesicles and resistance to weakly basic chemotherapeutic drugs. Biochem Pharmacol. 1999; 57:1047-1058.

46. Millot C, Millot JM, Morjani H, Desplaces A, Manfait M. Characterization of acidic vesicles in multidrug-resistant and sensitive cancer cells by acridine orange staining and confocal microspectrofluorometry. J Histochem Cytochem. 1997; 45:1255-1264.

47. Rauch C, Pleun A. Mutli drug resistance-dependent "vacuum cleaner" functionality potentially driven by the interactions 
between endocytosis, drug size and P-gp trasnporters surface density. Eur Biophys J. 2007; 36:121-131.

48. Castino R, Demoz M, Isidoro C. Destination 'lysosome': A target organelle for tumour cell killing? J Mol Recognit. 2003; 16:337-348.

49. Moriyama Y, Patel V, Ueda I, Futai M. Evidence for a common binding site for omeprazole and n-ethylmaleimide in subunit a of chromaffin granule vacuolar-type $\mathrm{h}(+)$-atpase. Biochem Biophys Res Commun. 1993; 196:699-706.

50. Yang Y, Niu X, Zhang Q, Hao L, Ding Y, Xu H. The efficacy of abraxane on osteosarcoma xenografts in nude mice and expression of secreted protein, acidic and rich in cysteine. Am J Med Sci. 2012; 344:199-205.

51. Raghunand N, He X, van Sluis R, Mahoney B, Baggett B, Taylor CW, Paine-Murrieta G, Roe D, Bhujwalla ZM, Gillies RJ. Enhancement of chemotherapy by manipulation of tumour ph. Br J Cancer. 1999; 80:1005-1011.

52 Keizer HG, Joenje H. Increased cytosolic ph in multidrugresistant human lung tumor cells: Effect of verapamil. J Natl Cancer Inst. 1989; 81:706-709.

53. Roepe PD, Wei LY, Cruz J, Carlson D. Lower electrical membrane potential and altered phi homeostasis in multidrug-resistant (mdr) cells: Further characterization of a series of mdr cell lines expressing different levels of p-glycoprotein. Biochemistry. 1993; 32:11042-11056.

54. Roepe PD. What is the precise role of human mdr 1 protein in chemotherapeutic drug resistance? Curr Pharm Des. 2000; 6:241-260.

55. Valverde MA, Diaz M, Sepulveda FV, Gill DR, Hyde SC, Higgins CF. Volume-regulated chloride channels associated with the human multidrug-resistance p-glycoprotein. Nature. 1992; 355:830-833.
56. Simon SM. Role of organelle ph in tumor cell biology and drug resistance. Drug Discov Today. 1999; 4:32-38.

57. Mickisch GH, Pai LH, Gottesman MM, Pastan I. Monoclonal antibody mrk16 reverses the multidrug resistance of multidrug-resistant transgenic mice. Cancer Res. 1992; 52:4427-4432.

58. Ferrari S, Perut F, Fagioli F, Brach Del Prever A, Meazza C, Parafioriti A, Picci P, Gambarotti M, Avnet S, Baldini N, Fais S. Proton pump inhibitor chemosensitization in human osteosarcoma: From the bench to the patients' bed. J Transl Med. 2013; 11:268.

59. Yang TT, Sinai P, Kain SR. An acid phosphatase assay for quantifying the growth of adherent and nonadherent cells. Anal Biochem. 1996; 241:103-108.

60. Baldini N, Scotlandi K, Serra M, Kusuzaki K, Shikita T, Manara MC, Maurici D, Campanacci M. Adriamycin binding assay: A valuable chemosensitivity test in human osteosarcoma. J Cancer Res Clin Oncol. 1992; 119:121126.

61. Fotia C, Avnet S, Kusuzaki K, Roncuzzi L, Baldini N. Acridine orange is an effective anti-cancer drug that affects mitochondrial function in osteosarcoma cells. Curr Pharm Des. 2015; 21:4088-4094.

62. Geran RI, Greenberg NH, Macdonald MM, Abbott BJ. Modified protocol for the testing of new synthetics in the 11210 lymphoid leukemia murine model in the dr\&d program, dct, nci. Natl Cancer Inst Monogr. 1977:151-153. 